\title{
Post-Endüstriyel İyimserlikten Hegemonik Despotizme: 21. Yüzyılın İlk Çeyreğinde Taşeron Çalışma ${ }^{1}$
}

Bahadir Nurol ${ }^{2}$

\section{Özet}

Taşeronluk sistemi 1980'lerin sonlarından bu yana günümüz firmalarının maliyet düşürme stratejilerinin bir parçası olagelmiştir. Ancak sistemin teorik meşruiyeti, yirminci yüzyılın son çeyreğinde popülerlik kazanan post-endüstriyel toplum teorilerine dayanmaktadır. Bu teoriler taşeron çalışmasını bağımsız, yaratıcı ve hayli yüksek vasıflı profesyonellere özgü bir iş olarak ele aldılar. Taşeronluk sistemi son on yıl içinde neredeyse bütün iş alanlarına sızdı. Ancak uygulamada, kamu sektöründeki pek çok işi dahi çalışanlar açısından güvencesiz hale getirdi. Buna bağlı olarak, post-endüstriyel toplum teorilerine yanıt olarak formüle edilen ve bu teorilerin karşısında konumlanan yaklaşımlar, taşeronluk sisteminin sanayi çağının ilk evrelerine has üretim ilişkilerini yeniden canlandırdığını öne sürdüler. Buna göre taşeronluk sistemi işyerlerinde despotik bir ilişki üretmeye eğilimliydi. Bu çalışmada, Michael Burawoy'un farklı emek rejimlerine yönelik kavramsallaştırmasından yararlanarak, taşeronluk sisteminin tarihsel despotizm ile rıza ve zorun bileşiminden oluşan çağdaş hegemonik despotizmin bir karışımı olduğu öne sürülecektir.

Anahtar Sözcükler: Taşeron çalışma, post-endüstriyel toplum, emek rejimleri, despotizm, hegemonik despotizm.

\footnotetext{
Abstract

Subcontracting has been part of contemporary firms' broader cost-reduction strategy since the late 1980s. The theoretical legitimacy of the system, however, based on the theories of the

${ }^{1} \mathrm{Bu}$ çalı̧sma SOB2015-10 no'lu proje kapsamında Ömer Halisdemir Üniversitesi Bilimsel ve Teknolojik Araştırma Projeleri Koordinatörlüğü tarafından desteklenmiştir.

${ }^{2}$ Yrd. Doç. Dr. Ömer Halisdemir Üniversitesi Sosyoloji Bölümü Öğretim Üyesi.

E-mail: bahadirnurol@gmail.com
} 
post-industrial society which gained popularity in the last quarter of the twentieth century. These theories regarded the subcontracted work that is specific to independent, creative and highly skilled professionals. In practice, however, subcontracting system has produced precariousness even in many of the formal sector jobs for the working people. Accordingly, some critical approaches were formulated in opposition to the theories of the post industrial society and they suggested that the subcontracting system has revitalized some pre-existing employment relationships that are specific to the first phases of industrial era. According to such approaches, the subcontracting system has tended to produce despotism in the workplace. In this paper, inspiring by Michael Burawoy's conceptualization of different production regimes, I will claim that the subcontracting system is a combination of historical despotism and contemporary hegemonic despotism as a regime of hybridized consent and coercion elements.

Keywords: Subcontracted work, post-industrial society, production regimes, despotism, hegemonic despotism.

\section{Giriş}

Neo-liberal küreselleşmenin simge isimlerinden Thomas Friedman (2005), küresel üretim zincirlerinin dünyanın dört bir yanında yeni ve yatay işbirliği biçimleri doğurduğundan söz eder. Ona göre söz konusu işbirliği, hem üretimin kimi kısımlarının farklı coğrafyalarda gerçekleştirilmesine imkân tanımakta, hem de büyük ve küçük şirketleri belirli işlevler için bir araya getirerek serbest ticaretin önüne dikilmiş engelleri yerle bir etmektedir. Açıktır ki bu işbirliği, üretim sürecinin kendi içinde parçalara ayrılmasına, ürünün her bir parçasının en uygun yerde üretilmesine, böylece sermayenin emeği en düşük maliyetle ve en verimli biçimde kullanma firsatına kavuşması sonucunu doğurmuştur (Ercan ve Özar, 2000: 35). Çalışanlar açısından uygulamanın pratikteki yansıması, bir önceki yüzyılın sürekli ve düzenli işlerinin yerini kitlesel ölçekte yarı zamanlı, geçici işlere bırakması olmuştur. Küresel üretim zincirleri hemen hemen tüm sektörlerde, dış kaynak kullanımının, istihdam ajanslarının ve bağımsız taşeronların yaygınlaşmasıyla eşzamanlı olarak yükselmiştir. Bilhassa bu çalışmanın konu edindiği taşeronluk sisteminin kapsamı, uygulamanın başladığı 1980'lerden 1990'l1 yılların ortalarına dek yalnızca G7 ülkelerinde üç katına çıkmıştır (Doogan, 2001: 421). 


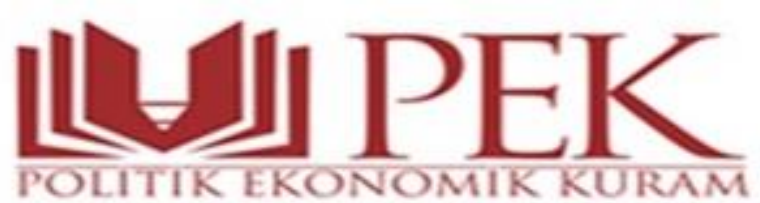

\section{(2017) Cilt 1(1)}

Taşeronluk sisteminin meşruiyeti iki temel varsayıma dayanmaktadır. İlkin, taşeronlaşma işgücü maliyetlerini düşürerek firmaların piyasada rekabet şanslarını yükseltecektir. İkinci olarak, kimi işlerin taşerona devredilmesiyle işyerinin ölçeği küçülecek, işçi sayısı azalacak ancak böylelikle çalışmanın etkinlik ve verimliliği artacaktır. Taşeron kullanımı, kullanım gerekçelerine bağlı olarak üç temel biçimde karşımıza çıkmaktadır. İlki, nihai üründe kullanılan kimi parçaların üretiminin ya da bu ürünün ortaya çıkma sürecinde gerçekleştirilen kimi işlemlerin o işi daha ucuz maliyetle gerçekleştirecek olan taşerona devredilmesidir. Bilhassa kitlesel üretim gerçekleştiren firmalarda taşeron kullanımı böylece, üretim miktarının artırılarak birim maliyetin düşürülmesine hizmet eder. İkincisi, kimi üretim faaliyetlerinin firma içinde gerçekleştirilmesinin mümkün olmadığı ya da aşırı masraflı bulunduğu durumlarda taşerona başvurulmasıdır. Üçüncüsü, firmaların kimi uzmanlık gerektiren teknik işleri taşeron firmalara devretmesidir. Bu yöntem bilhassa teknolojik donanım, yazılım ve diğer teknik uzmanlık gerektiren işlerin alt işveren tarafından karşılanmasıyla kendisini gösterir. Böylece firmalar, bir kez kurulduktan sonra muhtemel aksaklıklar ya da rutin gözden geçirme süreçleri haricinde her hangi bir işlem gerektirmeden uzun müddet kullanabilecekleri sistemler için, daimi personel istihdam etme ihtiyacından kurtulacaktır (Holtgrewe vd., 2009: 6; Tiyek, 2014: 11-12).

Taşeron kullanımının üç temel gerekçesi de, maliyet odaklı bir yaklaşımın olağan sonuçları olarak görülebilir. Ancak böylesi bir yaklaşım, konunun sosyolojik boyutunu göz ardı etmektedir. Oysa çağdaş sosyal bilimler literatüründe taşeronluk sistemini hem meşrulaştıran hem de hayli eleştirel bir incelemeye tabi tutan yaklaşımları içeren hayli derinlikli tartışmalar mevcuttur. Bu tartışmanın bir ayağında, 1970'li yıllarda kendisini gösteren, 1980'lerle birlikte bir bakıma ana akım niteliğine kavuşan post-endüstriyel toplum düşüncesi vardır. Postendüstriyel toplum düşüncesinin öncüleri, bilhassa mikro elektronik alanındaki gelişmelerin hâlihazırdaki örgütsel yapılanmalarda yarattığı ya da yaratması muhtemel değişiklikleri büyük bir iyimserlikle karşılamışlardır (Bell, 1974; Hirschhorn, 1984; Piore ve Sabel, 1984; Zuboff, 1988). Bu kampta yer alan yazarlar, özellikle Japon firmalarındaki taşeron kullanımından, Güney California'da yer alan Silicon Vadisi'ndeki firmaların örgütlenme tarzından ve İtalya'nın merkezi ve kuzey doğusunda 3. İtalya olarak da adlandırılan bölgede yoğunlaşan, küçük ve orta ölçekli işletmelerin başarısından etkilenmişlerdir. Post-endüstriyel toplum tezi 
taşeron kullanımını esas olarak, söz konusu bölgelerde yer alan firmaların kullandığı yüksek vasıflı, teknolojiye hâkim, bağımsız bir profesyonel gibi hareket edebilen, dünyadaki gelişmeleri yorumlayabilen, inisiyatif kullanabilen, beyaz yakalı taşeron firma çalışanlarından hareketle meşrulaştırmıştır. Post-endüstriyel toplum tezinin karşı kampında yer alan yazarlar, söz konusu işlerde çalışan kesimin, işgücünün son derece sınırlı bir bölümünü temsil ettiğini, sosyal devlet mekanizmalarının parçalanmasının işgücünün büyük kısmı için güvencesizleşmeden başka bir anlam taşımadığını, onların emek güçlerinin değersizleşme ve yoğun denetime maruz kaldığını, işlerin icrasına aktif olarak katılmalarına karşın işlerin tasarlanma aşamasında herhangi bir söz ve karar hakkına sahip olmadıklarını öne sürmüşlerdir. Kısacası, bu kampta yer alan yazarlara göre, taşeronluk sistemi sınaî kapitalizmin ilk dönemlerine benzer, despotik bir emek rejiminin ürünüdür (Andrade, 2002; Ennals 1999; La Botz, 2007; Yücesan-Özdemir, 2010).

Yukarıdaki satırlarda kısa bir özeti sunulan tartışmalar, zihinlerde taşeronluk sistemine dair farklı sorular uyandırmaktadır. Mikro-elektronik sanayindeki gelişmelerle sistemin yıpratıcı etkilerinin tarihe karışarak, taşeron çalışmasının özgürleştirici ve yaratıcı bir pratik olarak deneyimlenmesi mümkün müdür? Ya da taşeronluk sistemi teknolojiye hâkim, yüksek vasıflı ve inisiyatif kullanabilen yeni bir işçi sınıfının doğuşunu mu müjdelemektedir? Yoksa taşeronluk sistemi hâlihazırdaki güvenlik mekanizmalarını aşındırarak geniş toplum kesimlerini güvencesiz bir varoluşa sürükleyen temel aktörlerden birisi midir? Ya da taşeronluk sistemi sınaî kapitalizmin ilk yıllarındaki üretim ilişkilerine bir geri dönüşün güncel simgesi olarak mı görülmelidir? Bu sorulara verilen farklı yanıtlar günümüz emek rejimlerinin niteliğine dair farklı kavramsallaştırmalar üretmiştir. Bir yandan işbirliğine dayalı, özgürleştirici ve çalışanların rızasından beslenen bir emek rejiminden söz edilirken, öte yandan düpedüz despotik bir emek rejimi resmedilmektedir. Oysa bu makalede taşeron çalışma, rıza ve zorun kendine has bileşiminden oluşan "hegemonik despotik" bir emek rejiminin ürünü olarak sorunsallaştırılacaktır.

Yukarıdaki paragrafta dile getirilen soruların yanıtlarını aramak için, bu makalenin ilk kısmında çağdaş taşeronluk uygulamalarının kökenleri incelenecektir. İkinci kısım, yukarıdaki sorulara farklı yanıtlar üreten teorik yaklaşımların ayrıntılarıyla ele alındığı 
kısımdır. Üçüncü kısımda, taşeronluk sistemine dair özgün bir kavramsallaştırma arayışının izi sürülecektir ve sistemin "hegemonik despotik" nitelikleri sorgulanacaktır.

\section{Güncel taşeronluk sisteminin temelleri ve pratikteki yansımaları}

Kitlesel ve standart sınai üretimin damgasını vurduğu Fordist dönem, uzun vadeli ve geniş ölçekli sermaye yatırımlarıyla istikrarlı bir biçimde büyüme varsayımına dayanıyordu. Ancak 1973 petrol şoku sistemden kaynaklanan katılıkların daha fazla sürdürülmesinin mümkün olmadığ1 kanısını hâkim kıldı (Harvey, 1997: 161). Bu katılıklar Fordist üretim tarzından kaynaklanmaktaydı:

Standartlaşmış kitlesel seri üretim amacıyla tasarlanmış uzun montaj hatları boyunca parsellenmiş iş; yeni ürünler planlamak ve geliştirmek için üretimin örgütlenmesindeki katılık ve işgücünün aşırı uzmanlaşması yüzünden gerekli uzun süreler; katı ve neredeyse askeri hiyerarşi, kalabalık bir grup tarafından işçilerin denetlenmesi, işçilerin her birinin işini yaptığı yerde yalıtılmış olması, parsellenmiş görevlerin eşzamanlılaştırılması ile eşgüdümlenmesinin denetleyenler tarafından örgütlenmesi ve dayatılması; verime ilişkin normlar ile parça başına düşen zamanın -neredeyse saniyenin yüzde biri düzeyinde belirlenmiş katılığı, bir işin yapıldığ yerde meydana gelen gecikmenin zincirin tamamına yansıması; stoklar ve yüksek depolama giderleri; yaklaşık olarak işgücünün üçte birini temsil eden, doğrudan üretken olmayan işçiliğin önemi (Gorz, 2001: 44-45).

Katılıkların giderilmesi için, bir dizi yapısal reform önerisi gündeme gelmiştir. Michel Husson (2013) ilerleyen dönemde hayata geçirilen bu reformların temelinde yatan ilkelerin, esasen işgücü piyasalarının esnekleşmesini öngördüğünü ileri sürer. Bu ilkelerden ilkine göre, emek arzı ve talebi, herhangi bir piyasadaki (mesela patates piyasasındaki) gibi bir fiyat değişimiyle düzenlenebilmelidir. Bu ilkeye göre işsizlik, bu uygulamaya neden olan aşırı katılıkların yan ürünüdür. İkinci ilkeye göreyse, ücretliye yalnızca ürettiği zaman ödeme yapılmalıdır ki bu ilke ücretlerin de kati bir biçimde esnekleşmesini öngörmektedir. Kısacası esneklik, taşeronluk sisteminin yükselişinin ardında yatan temel unsurdur. Ancak dönem itibariyle, 
sistemi firmalar nezdinde bu denli popüler kılan örnek, taşeronluk uygulamasını uzun yıllardır sürdüren Japon firmalarının ulaştığı yüksek verimlilik göstergeleridir.

Japon işletmeciliğinde arzı talebe eşitlemek, ya da daha açık bir ifadeyle gerekli ürünleri gereken nicelikte, gereken nitelikte ve gereken zamanda üretmek başarının anahtarı olarak görülmüştür (Bratton, 1992: 23-26). Bu süreci yürüten büyük ve küçük Japon firmaları arasındaki ilişkinin en temel biçimi ise taşeronluk ya da shitauke sistemidir (Friedman, 1987: 360). Sistem, 1980'li yıllarla birlikte kimi değişikliklerle Batı’ya ithal edilmiştir. Japon taşeronluk sistemi, uzmanlık gerektiren işleri yerine getiren nispeten küçük firmalarla büyük ölçekli firmalar arasında, uzun döneme yayılan bir tedarik zinciri kurulmasını öngörür. Andrew Friedman (1987: 360-362) sistemin Bat1 ülkelerinde büyük heyecan uyandırdığ1 1980’li yılların ikinci yarısında kaleme aldığı çalışmasında, Japonya taşeronluk sisteminin kendisine has kimi niteliklerini şöyle sıralar: İlk olarak sistem pek çok farklı katmandan oluşmaktadır. Büyük bir firmadan taşeronluk işini alan bir firmanın, bu işi kendisinden daha küçük bir taşerona havale etmesi hayli sıradan bir uygulamadır. Sistem en tepesinde bir tek büyük firmanın bulunduğu ve alt katmanlara doğru inildikçe firma sayısının arttığı bir piramidi andırır. İkinci olarak, müşteri ve taşeron arasındaki ilişki bir ebeveyn çocuk ilişkisini andırır. Müşteri daima daha büyük ve teknolojik bakımdan daha yetkin olan firmadır. $\mathrm{Bu}$ firma pek çok taşeronla aynı anda iş görebilir ancak taşeronların müşteri sayısı sınırlıdır. Üçüncü olarak, müşteri bu ilişkide açıkça daha güçlü taraf olmasına karşın, taşeron firmayı tam anlamıyla hükmü altına aldığı durumlar nadirdir. Aralarındaki ilişki, bir tür sadakat ilişkisidir. Taşeron firmanın uzun müddet kendisiyle iş gören güçlü müşteriye sadakatinin göstergeleri, diğer müşteriler karşısında söz konusu firmanın işlerine öncelik tanıması, taahhüdünün zamanında yerine getirmesi ve zorlu koşullar altında dahi ürün kalitesinden taviz vermemesidir. Müşteri karşılık olarak, maddi açıdan sıkıntıya düştüğü dönemlerde yüksek vasıflı işçilerini elinde tutmak ve yeni teknolojilere yatırım yapmakta zorlanan birinci el taşeronlarına finansal ve teknik açıdan yardımda bulunur. Dördüncü olarak, müşteri-taşeron ilişkisini simgeleyen piramit durağanlıktan uzaktır. Taşeron firmalar hiyerarşide farklı katmanlara inip çıkarlar ya da bir diğer piramide geçmeyi tercih edebilirler. Ancak, taşeron firmalar için bu ilişkiden tamamen sıyrılarak, büyük müşteri rolüne bürünme olasıllı̆ı hayli düşüktür. Beşinci ve son olarak, Batılı muadillerinden belki de en büyük farklılığın işareti 


\section{(2017) Cilt 1(1)}

olarak, Japon sisteminde müşteri ve taşeron firmalar arasında personel alışverişi olağan karşılanır. Firmalar çalışanlarını, ücretlerini halen kendileri ödemek koşuluyla, geçici olarak diğer firmalara gönderebilirler. Bu ilişkide gönderici firma, genellikle müşteri konumundaki firmadır. Gönderilen personel, taşeron firmanın üretim ve satışlarını yükseltecek işletmecilik tekniklerini yürürlüğe sokmak, kimi zaman da onlara teknik yardımda bulunmakla mükelleftir. Bu kişiler, taşeron firmadaki üst düzey konumları geçici olarak sahiplenirler.

Taşeronluk uygulaması Batıya ithal edilirken Japon örneğindeki gibi sadakat içeren, ya da Friedman'ın sözleriyle ifade edersek bir ebeveyn ilişkisini andıran unsurlarından arınmıştır. Ancak müşteri-taşeron ilişkisini simgeleyen hiyerarşi piramidi olanca canlılığıyla hayata geçirilmiştir. Taşeron firmalar arasında büyük bir rekabet söz konusudur. Buna karşın müşteri konumundaki firmalar, taşeronlarla imzalanacak sözleşme bedellerini düşük tutmak için büyük gayret gösterirler. Açıkçası, Batıda sistematik biçimde yaygınlık kazanan model, Richard Sennett'in (2012: 198) benzetmesiyle sabit bir "ana iş" modeline karşı1t olarak örgütlenen "portföy" modeli olmuştur:

$\mathrm{Bu}$ modele göre birçok değişik ve alakasız etkinlik aynı şirket çatısı altında devam ettirilir. Portföy modelinin, hızlı değişen küresel pazarlara yanıt vermek ve eğer bir alanda yapılmıyorsa bir diğer alanda 'sayı yapabilmek' için bir yol olduğu iddia edilmiştir. Portföy kavramı uyumlu bir işbirliği görüntüsü ya da kimliğine karşı çalışır; işbirliği tasfiye edilebilecek, eklenebilecek ya da isteğe bağlı yeniden şekillendirilebilecek bir dizi tamamlayıcı parça olarak düşünülür.

Portföy modelinin sonucu, taşeronluk hizmeti satın alan firmanın, bu ilişkiden kimi yardımcı işlerde, asıl işin sınırlı bir bölümünde ya da teknolojik nedenlerle uzmanlık gerektiren işlerde istifade etme gereğini göz ardı ederek, işin büyük kısmını daha düşük maliyetle iş gören taşeron firmalara devretmesi olmuştur. Bu firmalar ve müşterileri son derece kaygan bir zeminde iş görerek rekabette bir üst basamağa tırmanmaya çalışmaktadırlar. Öte yandan kimi durumlarda iş hukukundaki kimi belirsizliklerden istifade ederek, taşerona iş devrini bir istisna olarak değil, adeta bir kural olarak algılama kolaylığına sapmışlardır (Okcan ve Bakır, 2010: 56-57). 


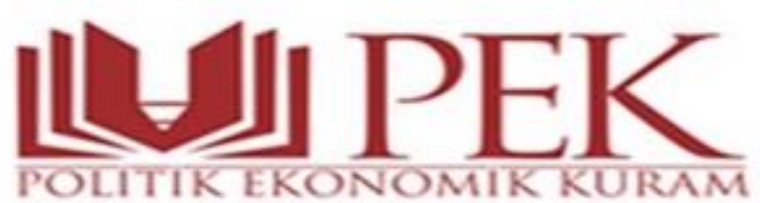

\section{(2017) Cilt 1(1)}

Taşeronluk faaliyeti yürüten firmalarda, firma içi hiyerarşiler son derece kaygan bir zeminde yapılanmıştır. Söz konusu hiyerarşi, firma çalışanlarının iş güvencesi ve itibar açısından farklı basamaklara dağıtılmasıyla kendisini gösterir. Japon örneğinde çoğu zaman firmayla özdeşlik kuran ve en azından işin yerine getirildiği süre boyunca işten ayrılmak zorunda kalmayacağını ve işin nerede görüleceğini bilen işçinin yerini Batıda, sözleşme süresinin herhangi bir anlam ifade etmediği, her an kendisini aynı taşeronun iş gördüğü bir başka çalışma sahasında bulması muhtemel işçiler almıştır. Söz konusu işçilerin uzun müddet aynı taşeronla çalışma olasılığı hayli düşüktür ve patronla işçi arasında kurumsallaşmış ilişkilerin görülme olasılığ1 hayli düşüktür (Gutelius, 2015: 58-59).

Japon örneğinde dile getirilen firmalar arası ve firma içi ilişkiler, açıkça görülmektedir ki, Batıya ithal edilirken bir hayli değişikliğe uğramıştır. Söz konusu ilişkilere yönelecek kestirme bir bakış, Japonya' daki sadakat ve dayanışma unsurlarının yerini Batıda son derece güçlü bir rekabete bıraktığını ileri sürecektir. Ancak Japon sistemi meşruiyetinin temelini geleneksel toplumsal ilişkilerde bulurken, Batıda bu meşruiyetin ataerkil ilişkilerin gücünden kaynaklandığını öne sürmek mümkün değildir. Aksine, sistem Batı'da hayli yoğun toplumsal çalkantıların ve teorik meşrulaştırma çabalarının ardından yaygınlık kazanmayı başarmıştır. Sisteme yönelik iyimserliği körükleyen temel yaklaşım, kabaca "post-endüstriyel toplum" başlığı altında sınıflandırılabilecek, farklı ekollerden yazarları çatısı altında toplayan yaklaşım olmuştur. Bu çalışmanın bir sonraki kısmı, söz konusu teorik meşrulaştırma çabaları ve doğurduğu tepkilerin ele alınacağı kısımdır.

\section{Taşeronluk sisteminin teorik meşruiyeti ve tepkiler}

Taşeronluk sistemine teorik destek sunan yazarların da, bu teorilerin meşruiyetini hayli eleştirel bir yaklaşımla sorgulayan yazarların da üzerinde uzlaşmaları hayli muhtemel olan konu, Fordist sistemin katılıklarını ortadan kaldırmayı amaçlayan yapısal reformların firmaların kurumsal yapılanışı adeta tersyüz etmiş olduğudur. Sennett (2009: 40-41) söz konusu kurumsal yeniden yapılanmaların, geleneksel firmaların üç temel yapıtaşını yerinden oynattığından söz eder. Bunlardan ilki, Fordist döneme ait bir firmada görevlerin ve önceliklerin sabit, önceden hesaplanan doğrultuda işleyen yapısının yerini artık çok işlevli ve değişken görev ve önceliklere bırakmış olmasıdır. Bu esnek firma tıpkı bir MP3 çalar gibi iş 


\section{(2017) Cilt 1(1)}

görür. Repertuarından yalnızca belirli kimi parçaları çalmaya programlanan bir MP3 çalar gibi, bu firma da belirli bir zaman aralığında pek çok olası işlevinden yalnızca belli birkaçını seçerek sadece o işlevleri yerine getirebilir. Üstelik bu şirket, şarkıların öncelik sıralaması sürekli değiştirilen bir MP3 çalar gibi, üretimin sırasını değiştirebilir. İkinci olarak, sabit ve durağan bir örgütlenme yapısına sahip olan Fordist dönem firmasının aksine, esnek firmalar kimi işlevleri başka firmalarca ya da başka yerlerde görülmesine imkân tanıyan taşeronluk sistemini kullanarak, firma içindeki katmanlarından kurtulabilir. Çalışan sayısı günün gereklerine göre artırılıp azaltılabilir. Üçüncü olarak, insanların bütün bir meslek hayatını aynı firmada ve aynı görevde sürdürebildiği Fordist dönem firmasının aksine, esnek firmalarda emek gücü geçicileşmiştir. Kısa vadeli sözleşmelerle işçiler müthiş bir rotasyona tabi tutulur, görevden göreve hareket ettirilir.

Sennett'in sözünü ettiği türden bir firma, post-endüstriyel toplum tezini savunan yazarlar açısından alkışlanması gereken bir başarıya imza atmış bir firmadır. Günümüzde dev üretim kombinalarının gelişmekte olan ülkelere ihraç edilmesiyle, sürekli yenilik prensibiyle hareket eden, adaptasyon yeteneği yüksek ve ağırlıklı olarak bilgi işlem teknolojilerine dayanarak iş gören firmaların yükselişi eşzamanlı olarak gerçekleşmiştir (Piore ve Sabel, 1984: 29). Böylesi bir firmanın ideal çalışanı, bilgi yoğun bir emek sürecini çalışmaktan haz duyarak özgürce yürüten, iyi eğitimli, yüksek vasıflı ve entelektüel bakımdan yetkinleşmiş beyaz yakalı profesyoneldir (Hirschhorn, 1984: Zuboff, 1988).

Post-endüstriyel toplum tezinin 1970'li yıllarda öne çıkan en tanınmış ismi, The Coming of Post-Industrial Society adlı çalışmasıyla Daniel Bell'dir. Post-endüstriyel toplumda önemsenen şey, Bell'e göre, "ham adale gücü veya enerjisi değil, enformasyondur. Merkezi konumdaki kişi, post-endüstriyel toplum tarafından giderek artan düzeyde talep edilen vasıfları sağlayacak eğitimle donanmış olan profesyoneldir" (Bell, 1974: 94). Bu toplum aynı zamanda, "toplumsal birimin bireyden ziyade topluluk olduğu, 'komünal' bir toplumdur." (Bell, 1974: 95) Dolayısıyla ideal örgütlenme biçimi şöyle ifade edilebilir: "Bilimsel dünyanın, özellikle bir araştırma topluluğunun örgütlenmesi, bunun görünümüdür. Hiyerarşi ve eşgüdümden çok, işbirliği ve karş1lıklılık” (Mattelart, 2004: 62). Bell, bu toplumun geride kalan endüstriyel toplumdan farkını ise şöyle açıklar: "Eğer bir endüstri toplumu, bir yaşam 
standardının alameti olan malların niceliğiyle tanımlanırsa, post-endüstriyel toplum günümüzde herkes tarafindan arzulanan ve elde etmesi mümkün olan sağlık, eğitim, eğlence ve sanat gibi hizmetler ve konforla ölçülen yaşam kalitesi ile tanımlanır” (Bell, 1974: 94).

Bell'in fikirlerini 1984 tarihli The Second Industrial Divide adlı çalışmalarında daha da ileri götüren Michael Piore ve Charles F. Sabel'in “esnek uzmanlaşma” tezi, bir bakıma taşeronluk sistemine yönelik bir güzelleme olarak okunabilir. Piore ve Sabel tezlerinde, sanayi örgütlenmesinin kitlesel üretim ve zanaat üretimi, yani esnek uzmanlaşma modeli olarak iki farklı döneme ayrılmış olduğu fikrini işlerler. Onlar kitlesel üretimi, "standart ürünlerin niteliksiz işgücü ve özel-amaçlı makineler kullanılarak büyük ölçekli üretimi” olarak görürken, esnek uzmanlaşmayı, "kalifiye işçiler ve esnek, genel-amaçlı makineler kullanılarak değişen, çeşitli ürünlerin küçük ölçekli imalâtı" olarak tanımlarlar (Taymaz, 1993: 8). Tarihsel bakımdan ele alındığında, on dokuzuncu yüzyıl sonları kitlesel üretimin doğuşuyla ortaya çıkan "birinci sanayi ayrımı”na işaret ederken, yirminci yüzyılın son çeyreği artık “ikinci sanayi ayrımı”na gelindiğini müjdelemektedir: “Geriye dönüp bakıldığında, 1970’ler ve 80 'ler, makineleşme tarihinde bir dönüm noktası olarak görülecektir: sanayi toplumunun, on dokuzuncu yüzyıldan beri marjinal addedilen zanaat metotlarına geri döndüğü zamanlar olarak..." (Piore ve Sabel, 1984: 252).

Piore ve Sabel için esnek uzmanlaşma dinamik ve kalıcı bir süreçtir. Çünkü öncelikle, bilgisayar teknolojisi dünyayı geri dönülemez biçimde değiştirmektedir. Bu teknoloji ve esneklik arasında güçlü bir ilişki vardır. Bilgisayarın sanayide kullanılması esnek sistemleri güçlendirmektedir. Ancak bilgisayar teknolojisi tek başına zanaat metotlarına geri dönüşü sağlayamaz. Bunun için, esnekliğe prim tanıyan rekabetçi bir ekonomiye geçilmesi gerekir (Piore ve Sabel, 1984: 261). Bu koşulların birlikteliği, esnek uzmanlaşmayı doğurmuştur. Söz konusu model ekseninde örgütlenen firmalar dört farklı biçimde ortaya çıkabilirler: İlki, hiçbir işletmenin piyasada sürekli bir hâkimiyet kurmadığı, aralarındaki ilişkilerde rollerin sürekli değiştiği ve kısa vadeli sözleşmelerle belirlendiği "bölgesel kümelenmeler"dir. Bunun örnekleri, kuzey ve orta İtalya'nın sanayi bölgeleri, New York'ta ki konfeksiyoncular bölgesi ve ABD’nin bir dizi şehrindeki inşaat endüstrisinde görülebilir. Esnek uzmanlaşmanın ikinci biçimi, savaş öncesi Japon zaibatsu' ları ile bağlantı kurularak tartışılan “federe girişimler”dir. 


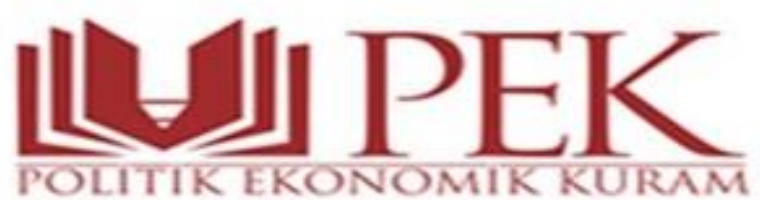

\section{(2017) Cilt 1(1)}

$\mathrm{Bu}$ girişimlerde mali sözleşmeler ile personel sözleşmeleri birbirine kenetlenmiştir. Firmalar bir diğerinin stoklarını elinde tutabilir, birbirlerinin mali ve pazarlama imkânlarından faydalanabilir. Aynı zamanda menajerler federasyonu oluşturan firmalar arasında gidip gelebilir. Firmalar arasında bir hiyerarşiden söz edilemez ve ortak bir kimlik duygusu hâkimdir. Esnek uzmanlaşmanın üçüncü ve dördüncü biçimleri ise sırasıyla, "solar firmalar" ve "atölye fabrikalar" olarak adlandırılır. Piore ve Sabel solar firmaları, bir güneş sisteminde alıcıların yörüngesinde dolanıp duran gezegenlere benzetir. Atölye fabrikalar ise, solar firmaların yakın akrabası olan, esnek, yoğun teknoloji kullanarak süratle üretime geçen imalathanelerdir (Piore ve Sabel, 1984: 265-267).

Farklı biçimlerde karşımıza çıksalar da, bu firmaların hepsi de esneklik ve uzmanlaşmayı bir araya getirmiştir. Esnektirler, çünkü "bileşenlerinin yeniden düzenlenmesi yoluyla üretici süreçleri sürekli yeniden biçimlendirme kapasitesine sahiptirler. (Piore ve Sabel, 1984: 269). Uzmanlaşmışlardır, çünkü mümkün olan düzenlemelerin sınırları bellidir ve yayılma kapasiteleri kısıtlıdır. Öte yandan, bu örgütlenmeler alana dışarıdan girişi sınırlamışlardır. Aksi halde sistemin kapasitesi zorlanmaya başlayacak ve refah düzeyi düşecektir. Bununla birlikte, söz konusu örgütlenmelerde rekabet teşvik edilir. Örgüt içindeki rekabet baskısı, firmalar arasında genel anlamda kabul gören hiyerarşide avantajlı bir konuma geçme arzusundan doğarken, esnek uzmanlaşmayı benimsemiş farklı topluluklar arasında da bir rekabet söz konusudur. Yine de bu rekabet belli sınırlara tabidir. Ücretler ve çalışma koşulları belli bir seviyenin altına çekilemez. Çünkü hem yenilikleri teşvik eden rekabeti güçlendirmek, hem de esnekliğin ihtiyacı olan kurumsal bağlılığı sürdürmek için emek sömürüsüne kurumsal bir sınır getirilmiştir (Piore ve Sabel, 1984: 268-272). Kısacası, esnek uzmanlaşma tezine dayanarak, taşeronlaşmanın, son derece yetkin bir teknolojik donanıma sahip firmaların, büyük bir esneklikle farklı alanlara yayılan işleri görmesine imkân tanıyan bir sistem olarak görülmesi mümkündür.

1980’li yıllarda, söz konusu yaklaşıma ampirik bir temel kazandırmak amacı güden sosyoloji kökenli isimler, yeni teknolojilerin devreye girmesiyle, otoriter bürokratlar ve geleneksel kapitalizmin koyduğu engellerin artık ortadan kalktığını müjdeler. $\mathrm{Bu}$ isimlerin önde gelenlerinden Larry Hirschhorn, sistemin karmaşılığı arttıkça, sistemin tüm bilgisine sahip 
işçilerin varlığının acil bir gereklilik halini aldığını ileri sürer. Bu işçiler, ömrünü bir tek firmada tüketen geleneksel sınai işçilerinden hayli farklıdır. $\mathrm{Bu}$ işçiler, post-endüstriyel dönemin işçileridir ve "bütün üretim sürecini inceleyip anlayabilmelidir ki böylece öngörülemeyen aksilikleri gidermeye hazır olabilsinler" (Hirschhorn, 1984: 2). Yeni enformasyon teknolojileri ise, Hirschhorn'a göre, "post-endüstriyel” teknolojilerdir. Bu teknolojiler, işçileri fiziksel yorgunluktan ve can sıkıntısından kurtarır ama aynı zamanda onların sürekli bir hazırlık ve öğrenme sürecinde olmasını zorunlu kılar. Söz konusu akımın bir diğer önemli temsilcisi Shoshana Zuboff, geleneksel tekniklerle çalışan işyerlerinde kurumsal deneyimin geleneksel rolleri yeniden üretecek biçimde yapılandırıldı̆̆ını ifade eder. $\mathrm{Bu}$ işyerlerinde menajerler, "emretme imtiyazlarının devamı için ısrar ederler ve kendilerini astlarından ayırt edecek hiyerarşik mesafeyi koruyacak metotları bulmaya çalışırlar” (Zuboff, 1988: 6). Oysa Zuboff’ a göre, enformasyon teknolojisine dayalı işyerlerinin örgütlenmesi bu anlayışa radikal bir alternatif sunar. $\mathrm{Bu}$ alternatifte ilişkiler, işbirliği temelinde kurulmak zorundadır ve sınırları meslektaşların karşılıklı sorumluluğuyla çizilmektedir. Böylece, “menajer ve işçilerin her biri kendi dar işlevsel perspektiflerinin üstesinden gelirken, verizengini bir ortamda, değer katan faaliyetlere daha uygun yeni roller yaratırlar" (Zuboff, 1988: 6). Sonuç olarak, "Her bir kurumsal düzeyde vasıfların kalitesi birbirine yaklaştıkça, hiyerarşik ayrımlar bulanıklaşmaya başlar" (Zuboff, 1988: 6). Bundan sonra otorite, bilgi ve sorumluluğun demokratik bir bileşimi üzerinden şekillenecektir.

Yukarıdaki satırlarda kimi önde gelen örnekleri sunulan post-endüstriyel toplum teorileri, taşeronluk sisteminin meşruiyet kazanmasında hatırı sayılır bir role sahiptir. $\mathrm{Bu}$ tezler öncelikle, büyük firmaların kitlesel ölçekli üretim gerçekleştirdiği, standart çalışma düzenine sahip Fordist sistemin yerini esnek, yaratıcı ve bilgi temelli üretim gerçekleştiren firmaların aldığını vurgulayarak, günümüzde çalışmanın itibar kazandığını öne sürmüşlerdir. İkinci olarak, geleneksel denetimin yerini, kültürel koordinasyon, içselleştirilmiş bir bağlılık ve işçilerin öz disipliniyle yürütülen bir emek sürecine bırakmasına yönelik vurgularıyla, bağımsız profesyonelliği yüceltmişlerdir. Üçüncü olarak, örgüt ve firma hiyerarşilerinin yerini ağların, sınırları belirsiz ve bir merkezi olmayan birimlerin aldığını iddia ederek, taşeron firmaları hak ettiklerinin çok ötesinde bir iyimserlikle selamlamışlardır. Ancak bu iyimserlik yoğun eleştirileri de beraberinde getirmişstir. 
Öncelikle çoğu yazar, söz konusu teorilerin teknolojiyi özerk bir güç olarak ele aldıklarını öne sürmüştür. Buna göre, post-Fordist yaklaşımda teknolojik gelişme sanki üretim ve çalışma koşullarını kendi başına dikte ediyor gibi algılanmaktadır (Knights ve Murray, 1994; Kiely, 1998; Thompson, 2003; Mattelart, 2004). Böylece teknolojik değişim sürecinde yaşanan iktidar ve siyaset ilişkileri gözlerden gizlenmektedir (Knights ve Murray, 1994: 10). Yine de bu söz konusu teknolojik determinizm, hayli inatçı bir mit olarak görülmektedir: "Teknolojik determinizm kendiliğinden ve kaçınılmaz bir ilerleme içinde gibi görünüyor, bu bir anlamda Darwinci hayatta kalma anlayışına benziyor, sadece en 'uygun' yenilikler hayatta kalabilecek ve sadece bu yenilikleri uygulayabilenler refaha ulaşacak" Grint ve Woolgar, 1997:11'den aktaran, Bradley vd., 2002: 101). Kimilerine göre ise, post-Fordist yaklaşımı sahiplenen yazarlar bir tür teknoloji tacirliği yapmaktadır. Çünkü bu yaklaşıma göre, "Belleğini yitirmiş, toplumsal tasarıdan yoksun bir modernlik adına yürürlükten kalkmayan hiçbir şey kalmaz. Sonsuz ve sınırsız iletişim, sonsuz ve sınırsız ilerlemenin kalıtçısı olarak kurulur” (Mattelart, 2004: 123-124). Açıktır ki, bu teorilerden yola çıkan analizlerde, taşeron firmalar sanki yalnızca teknoloji yoğun ve yüksek vasıf gerektiren işleri kapsıyormuşçasına, söz konusu firma modelinin dünya çapında asıl görünürlüğünü düşük vasıf gerektiren, emek yoğun işlere borçlu olduğu açıkça göz ardı edilmiştir. Dolayısıyla, taşeron sisteminin hali hazırdaki meşruiyetini sorgulayan güncel çalışmalar, taşeron firmalarda iş gören geniş işçi kesimlerinin çalışma koşullarını yeni ve özgürleştirici bir aşamadansa, sanayi devriminin ilk yıllarındaki koşullarla benzerlik kurarak açıklama yolunu seçmişlerdir.

Eleştirel hatta yer alan yaklaşımların en sık vurguladığı temalardan birisi, esnek çalışmanın hâkim olduğu pek çok işyerinin "vahşi kapitalizm" dönemine benzer deneyimlere yataklık ettiğidir (Andrade, 2002; La Botz, 2007). Bu isimlerden Dan La Botz (2007: 60), günümüzde işyerlerinin, işgücünün ve işgücü piyasasının hızlı ve derin bir dönüşüm sürecinde olduğunu vurgulamaktadır. $\mathrm{Bu}$ dönüşümün en açık gözlenebileceği alanlardan birisi ise taşeron çalışmasıdır. Üstelik piyasadaki taşeron işlerinin büyük bir çoğunluğu işyeri demokrasisinden nasibini almamış, işçi-işveren ilişkisinin her türlü kurumsallıktan uzak, keyfi niteliklere büründüğü işlerdir. Taşeronluk sistemi kadınları, gençleri ve belirli bir yaşın üzerindeki işçileri yoğun ve istem dışı rotasyona tabi tutarak büyümektedir (Ennals, 1999). Dahası, Yücesan-Özdemir'in (2010) ifadesiyle, taşeron çalışma açıkça “despotik” bir emek rejimidir. 
Yazar söz konusu saptamasının gerekçelerini sekiz madde halinde sıralamaktadır: (1) Taşeron işçilerin karşılaştıkları çalışma düzeni şu unsurlardan oluşur: yüksek işçi rotasyonu, işler arasında rotasyon, çalışma mekânlarının sürekli değişmesi, düşük ücret, hak kayıpları, ağır çalışma koşulları, sosyal güvenceden, sağlık ve işçi güvenliğinden mahrumiyet. Bu unsurlar tam anlamıyla despotik bir emek rejimine has unsurlardır. (2) Taşeron firma ile müşteri firmanın ilişkisi, baskı koşullarını sürekli yeniden üreten bir bağımlılık ilişkisidir. Müşteri firma kendi çalışanlarına göreli yüksek ücret ve sosyal güvence sunar ve kimi zaman sendikalaşma imkânı tanırken, baskı altındaki taşeron firmayı kendi işçilerinin hakları konusunda sürekli yeni tavizler vermeye mahkûm etmektedir. (3) Taşeron firmalar arası rekabet, bir tür "dibe doğru yarış" anlamı taşır. İhaleyi alabilmek için yaptıkları fedakârlıkların karşılığı, işçilerin çalışma koşullarının giderek kötüleşmesiyle alınır. (4) Taşeron çalışma işçiler arasında yeni bölünmeler ve katı hiyerarşiler yaratmaktadır. (5) Sendikal güvenceden yoksunluk, taşeron işçileri teslimiyete sürükler. (6) Aynı taşeron firmanın işçileri kendi aralarında mekânsal ve kurumsal bakımdan parçalanmıştır. (7) Beyaz yakalı emekçiler de baskı mekanizmasından payını almaktadır. (8) Taşeron çalışması, işçi denetiminde rızadan çok baskı mekanizmalarından destek alır. Bütün bu koşulların hâkimiyeti, açıkça, despotik bir emek rejiminin varlığıyla mümkündür. (Yücesan-Özdemir, 2010: 42-44).

Yukarıdaki satırlarda özetlenen despotik emek rejimini, her şeyden önce, çalışma hayatını düzenleyen yasal mekanizmaların gevşetilmesine, kimi zaman da düpedüz ilgasına bağlıdır. Yasal prosedürlerin esnekleştirilmesi çalışma yaşamında açık bir gerilemeyi simgeler. Dolayısıyla eleştirel hatta yer alan çalışmaların sıklıkla üzerinde durduğu bir diğer husus, taşeronluğun yasal yükümlülüklerden kaçınma amacıyla başvurulan bir yöntem olmasıdır. İşyerinin göreli büyüklüğünden doğan yükümlülüklerden kaçınmak için firmalar, kimi işleri taşerona devrederek, işyerini bölünerek küçülmüş gibi gösterirler (Tiyek, 2014: 11). Öte yandan işçi ve işveren arasında aracılık görevini üstlenen taşeron ajansları, işçilerle imzaladıkları açık uçlu sözleşmelerle, doğrudan istihdama alternatif bir sistem oluştururlar (Enright and Pemberton, 2016: 9). Bu alternatif fiiliyatta çoğu zaman işveren sorumluluklarının ajans ve alıcı firma arasında kalarak, göz ardı edilmesi sonucunu doğurur. 
Kısacası, yukarıdaki açıklamaların genel bir değerlendirmesini sunarsak, taşeronluk sistemini bir tür ilerleme olarak sunan çalışmaların karşısına, sistemin açık bir geriye gidiş olduğunu savunan çalışmaların dikildiğini görürüz. İlk hatta yer alan yazarlar ampirik verilerini ağırlıklı olarak ileri teknoloji kullanan, ağırlıklı olarak yüksek vasıflı işgücü istihdam eden firmalar özelinde yürütülmüş çalışmalara dayandırmaktadır. Oysa ikinci hattın verileri ağırlıklı olarak, dünya genelinde taşeron çalışanların çok daha büyük bir kesimini içeren imalathaneler, sınai üretim gerçekleştiren işletmeler ve düşük vasıflı hizmet sektöründeki işler üzerinde yoğunlaşmaktadır. Her iki hattın da ortak vurgusu esneklik üzerinedir. Ancak olumlayıcı yaklaşım esnekliği bir özgürlük alanı olarak sunarken, eleştirel yaklaşım güvencesizlikle özdeşleştirmekte ve taşeron çalışmada gerçek bir boyunduruğun ortaya çıkış koşullarını görmektedir. Açıktır ki taşeron çalışmanın bir ilerleme olarak adlandırılması hayli zor görünmektedir. Ancak taşeronluğun açık bir gerileme mi, yoksa günümüze has son derece çelişkili unsurların toplamında billurlaşan ve çağdaş bir tahakkümün koşullarını yaratan bir mekanizma mı oluşturduğu konusu tartışmaya açıktır. $\mathrm{Bu}$ makalenin ilerleyen kısmında taşeronluğu işte bu ikinci yönüyle kavramsallaştırma çabası güdülecektir.

\section{Taşeron çalışmanın güncel bagajı: Hegemonik despotizm}

Güncel taşeronluk uygulamaları ne düpedüz tarihsel bir gerileme ne de açı bir özgürlük alanı olarak görülmelidir. Aksine, taşeronluk farklı emek rejimlerini simgeleyen her bir istasyonda inerek, bagajına kendisine gereken unsurları doldurduktan sonra yoluna devam eden, son derece eklektik bir çalışma düzenini temsil etmektedir. Söz konusu emek rejimlerinin yetkin bir kavramsallaştırmasını sosyolog Michael Burawoy'un Politics of Production (1985) adlı çalışmasına borçluyuz. Burawoy sözkonusu çalışmasında emek rejimlerini üç farklı tarihsel aşamada ele almaktadır. Bu aşamaların ilki, Burawoy’un sınaî kapitalizmin ilk yıllarıyla özdeşleştirdiği “piyasa despotizmi”dir. Piyasa despotizmi, Marx'1n Kapital'de çözümlediği fabrika rejimidir ve zora dayanır. $\mathrm{Bu}$ aşamada, yaşamını sürdürmek için diğer geçim olanaklarından mahrum bırakılmış emekçi, işgücü piyasasında var olmak ve kapitalist için çalışmakla açlıktan ölmek arasında seçim yapmak durumundadır. (Burawoy, 1985: 123-124). Marx (2011: 465-466), Kapital'de söz konusu rejimin temel unsurlarını şu sözlerle açıklamıştır: 
Modern sanayi, bir üretim sürecinin mevcut biçimini hiçbir zaman kesin bir biçim olarak görmez ve böyle ele almaz. İşte bu nedenle, önceki tüm üretim tarzlarının özleri açısından tutucu olmasına karşın, onun teknik temeli devrimcidir. Makineler, kimyasal süreçler ve diğer yöntemler aracılığıyla, sürekli olarak, üretimin teknik temeli ile birlikte işçilerin işlevlerini ve emek süreçlerinin toplumsal bileşimlerini değişikliğe uğratır. Böylece toplumun içindeki iş bölümünde de sürekli dönüşümlere yol açar; sermaye ve işçi kitlelerini durup dinlenmeksizin bir üretim kolundan çekip bir başka üretim koluna firlatır. Bundan ötürü büyük sanayi, doğası gereği, bir yandan iş için değişmeyi, işlevler için akıcılığı, emek için tam bir hareketliliği gerekli kılarken, bir yandan da kendi kapitalist biçimi içinde, eski iş bölümünü, bunun katılaşmış özellikleriyle birlikte, yeniden üretir. Bu mutlak çelişkinin, işçinin hayatında huzur ve sükûndan, kararlılık ve güvenden nasıl eser bırakmadığını; işçiyi emek araçlarından yoksun bırakarak devamlı bir biçimde nasıl geçim araçlarından da yoksun bıraktığını, işçinin bir bütünün ancak bir parçasını yapan bir kimse haline sokarak işçileri mevcut işlere oranla nasıl bollaştırdığını görmüş bulunuyoruz. Yine görmüş olduğumuz gibi, bu çelişki işçi sınıfının ardı arkası kesilmeksizin kurbanlar vermesinde, insan emek gücünün ölçüsüz bir biçimde israf edilmesinde ve nedeni olduğu toplumsal anarşinin yol açtığ1 yıkımlarda olanca çılgınlığg ile kendini gösterir.

Burawoy’un sözünü ettiği ikinci emek rejimi, "hegemonik rejim"dir ve kapitalizmin savaş sonrası sosyal devlet ${ }^{3}$ safhasına karşılık gelir. $\mathrm{Bu}$ rejimde işletmeler, işgücü piyasasının zorlamalarına eskisi denli bel bağlayamadığı gibi, işçiye despotça davranmaktan kaçınmak zorundadır. Çünkü artık, "Baskının rızaya üstün geldiği, kapitalizmin erken dönemlerini simgeleyen despotik rejimler yerini rızanın üstün olduğu hegemonik rejimlere” bırakmıştır. (Burawoy, 1985: 126) Şimdi işçilerin, "yönetimle işbirliğine gitmesi için ikna edilmesi gerekmektedir. Çıkarları, sermayenin çıkarlarıyla uyum içinde olmalıdır." (Burawoy, 1985: 126) Bu rejimde, devletin sunduğu sosyal güvenceler, işçinin hayatta kalmak için işverenin her türlü kaprisine boyun eğme zorunluluğunu ortadan kaldırmıştır.

\footnotetext{
${ }^{3}$ Sosyal devletin parçalanmasına dair bkz. Berberoglu, 2002 ve Harvey, 2010, 2012.
} 


\section{(2017) Cilt 1(1)}

Üçüncü aşamada beliren rejim günümüze özgüdür ve Burawoy bu rejimi "hegemonik despotizm" olarak adlandırır. Burada baskı kendisini sınaî kapitalizmin ilk yıllarında sahip olduğu açılıkla göstermez. Ancak bir kere, bir önceki dönemin rıza mekanizmalarına hayat veren sosyal güvenlik kurumları aşınmıştır. $\mathrm{Bu}$ rejimde sermayenin kazandığı olağanüstü ulusal ve uluslararası hareketlilik imkânı işçilerin elini zayıflatır. Çünkü bu rejimde sermayenin gözettiğgi ölçüt, "firmanın bir yıldan ötekine sağladığı başarı değil, başka bir yörede elde edebileceği kar oranıdır" (Burawoy, 1985: 150). Dolayısıyla bu kez, "İşten kovulma korkusu yerini, sermayenin başka bölgeye kaçışı, fabrikanın kapanması, işletmenin devri ve yatırımın sonlandırılması korkularına bırakmıştır” (Burawoy, 1985: 150). Böylece bu yeni rejimde işçiler, firmanın ayakta kalabilmesi için sürekli yeni fedakârlıklarda bulunmaya zorlanır. Bir önceki dönemin özerk alanları, yeni koşullara yönelik rıza yaratmayı amaçlayan yaşam kalitesi ve kalite çemberleri gibi uygulamalarla istila edilir. Bu uygulamalara "Sendikaların yetkisini kısmak ve sendika faaliyetlerine katılan işçileri kovmak için gösterilen güçlü çabalar” eşlik eder (Burawoy, 1985: 151). Hegemonik despotizm çemberi nihayet, devletlerin sermayeyi kendi ülkelerine çekmek için birbirleriyle girdikleri yarışla tamamlanır. $\mathrm{Bu}$ yarış kendisini vergi indirimleriyle, iş yasaları ve sosyal devlet uygulamalarının sermayeyi cezp edecek biçimde, yeniden yapılandırılmasıyla göstermektedir (Burawoy, 1985: 151).

Burawoy'un kavramsallaştırmasından yola çıkan bir taşeronluk sistemi analizi, bir önceki kısımda özetlenen eleştirel yaklaşımlarda görüldüğü üzere, sistemi “piyasa despotizmi” ile özdeşleştirmeye yatkındır. Üstelik söz konusu özdeşlik için sunulan gerekçeler, hiç de yabana atılacak türden gerekçeler değildir. Ancak Marx'ın yukarıda alıntılanan ve modern sanayinin, bir üretim biçiminin mevcut biçimini hiçbir zaman kesin bir biçim olarak görmediğine dair sözlerini temel alırsak, günümüz taşeronluk sisteminin despotik rejimle hegemonik despotizmin kendine has bir bileşkesinden oluştuğunu öne sürmek mümkündür. Söz konusu bileşkenin unsurları aşağıdaki satırlarda yer alan yedi ana madde halinde özetlenebilir.

İlk olarak, her iki emek rejiminde de işçiler, yüksek iş değiştirme hızı, düşük ücretler, ağır çalışma koşulları ve sosyal güvencesizlikle karşı karşıyadır. Ancak günümüz taşeron işçileri bu koşulları sınaî üretimle ilk kez karşılaşan ve çalışma haklarını zamanla, mücadele içinde 


\section{(2017) Cilt 1(1)}

elde edecek olan despotik rejimdeki muadillerinin aksine, bir hak kaybı olarak deneyimlemektedirler.

İkinci olarak, her iki emek rejiminde de sendikal faaliyetler hayli zayıftır. Ancak kitlesel ölçekli üretim yapılan büyük fabrikaların belirginleştiği despotik rejim sendikaların aktif müdahalesinin koşullarını yaratırken, küçük ölçekli üretim ve dağınık bir işgücüyle simgelenen hegemonik despotizm çağının taşeron işçileri için sendikal mücadelenin koşulları giderek aşınmaktadır.

Üçüncü olarak, despotik emek rejiminde günümüzün beyaz yakalı tabiriyle anılan meslekleri yukarıda dile getirilen koşullardan muaf olmalarına karşın, hegemonik despotizmin sınırları bu kesimleri de güvencesiz taşeronluk sistemine dâhil edecek kadar genişlemiştir.

Dördüncü olarak, her iki emek rejiminde de firmalar arası rekabet, ücretler, çalışma koşulları ve iş güvencesinin aşınması sonucunu doğurmaktadır. Ancak, despotik rejimde söz konusu koşullara yönelik rızanın yegâne temeli işten kovulma korkusuyken, hegemonik despotizmde buna sermayenin başka bölgeye kaçışı, fabrikanın kapanması, işletmenin devri ve yatırımın sonlandırılması korkuları eklenmiştir.

Beşinci ve bir üstteki maddeyle bağlantılı olarak, her iki rejimde de işçi, daha çok çalışmaya, daha fazla fedakârlıkta bulunmaya zorlanmaktadır. Ancak despotik rejimde fedakârlık işçinin fiziksel kapasitesini son haddine dek zorlaması anlamına gelirken, hegemonik despotizmde işçinin yoğun fiziksel çalışmanın üstüne bir de bu fedakârlığı içselleştirmesi, kendini firmanın amaçlarıyla özdeşleştirdiğini her geçen gün yeniden kanıtlaması beklenmektedir.

Altıncı olarak, her iki rejimde de işçiler yoğun denetim altında çalışmaya zorlanmaktadır. Ancak despotik emek rejiminde denetim dolaysız biçimde bir üst kademede yer alan amirlerce gerçekleştirilirken, hegemonik despotizm döneminde buna teknolojik denetim unsurları eklenmiştir.

Yedinci olarak, despotik rejimde işçi, çalışma koşulları ve temel haklarına yönelik iyileştirmeler için ulusal siyaseti ve ulusal kurumları zorlarken, hegemonik despotizmde buna halihazırdaki koşulları empoze eden uluslararası kurumların küresel çaptaki etkisiyle de 


\section{(2017) Cilt 1(1)}

mücadele etme gerekliliği eklenmiştir. Üstelik sendikaların güçten düştüğü günümüz koşullarında işçi, böylesi bir mücadelenin araçlarından yoksundur.

\section{Sonuç}

Taşeronluk uygulaması 20. yüzyılın büyük bir bölümü boyunca sosyal devlet uygulamalarının gereği olarak yaygınlık kazanamamıştır. Sosyal devlet dönemi, Richard Sennett'ın (2005: 85) ifadesiyle, "iktisadi bireycilik ile topluluk isteği arasındaki uçurumu giderme" çabasının ürünüydü. Keynesyen döneminin piyasa mekanizmasının özlemleriyle bağdaşmayan nitelikleri, çalışanlara ömür boyu iş güvencesi, statüye göre derecelendirilen ücretler ve aynı firma içinde zamanla üst basamaklara çıkılacak bir kariyer vaat ediyordu. Ancak sistemin çelişkisi, sağladığ1 iş güvencesi ve ücret garantisinin, ekonominin krize sürüklendiği ve iş hacminin daraldığı zamanlarda, ücretleri ve işçi sayısını istediği gibi esnetmesini engellemesinden ileri geliyordu (Edwards, 1979: 157). Bu koşullarda taşeron kullanımı öncelikle mali gerekçelerle meşruiyet kazanmıştır. Öte yandan, yüzyılın son çeyreğinde hayli etkili olan "post-endüstriyel toplum" teorileri, kısa dönemli işler arasında salınan, parçalanmış bir kariyer modelinde somutlaşan çalışmayı, bürokratik engelleri, boğucu ve rutin bir iş yaşamını ortadan kaldıran esaslı bir gelişme olarak selamladılar. Söz konusu teoriler, taşeronluk sistemine yönelik düşünsel meşruiyetin doğuşunda hatırı sayılır rol oynadı. Zira bu teorilerin başat varsayımına göre sistem, giderek yetkinleşen ve yeni bir özgürlük alanının müjdecisiydi. Bu hatta yer alan çalışmaların dayandığı ampirik malzeme, ağırlıklı olarak, teknoloji yoğun sektörlerde çalışan, yaratıcı ve yüksek vasıflı işgücü üzerinden kamuoyuna sunuldu. Artan eğitim olanakları ve teknolojik imkanların yoğunlaşması, sisteme yönelik iyimserliğin temelinde yatıyordu. Bu süreçte söz konusu akımın öngörülerine şüpheyle yaklaşan çalışmalar, sistemin toplumun geniş kesimleri açısından doğurduğu yıpratıcı koşulları vurguladılar. Bir kere, post-endüstriyel toplum teorilerinde ileri sürülen varsayımların aksine, taşeronluk sistemi yalnızca yüksek vasıflı, teknolojiye hâkim ve yaratıcılık gerektiren işlerle sınırlı kalmamış, halihazırdaki hemen bütün işlere sızmıştı. Üstelik sistem yarattığı güvencesiz çalışma modeliyle, yüksek vasıf gerektiren işlerde çalışan kesimleri de yıpratmaya başlamıştı. Dolayısıyla eleştirel yaklaşımların başvurduğu başlıca metafor, taşeron çalışmanın endüstriyel kapitalizmin ilk dönemlerine benzer, despotik bir 


\section{(2017) Cilt 1(1)}

çalışma düzeni yarattığını vurgulamak oldu. Ancak çağdaş taşeronluk sistemi bu makalede vurgulandığı üzere, tam anlamıyla günümüze has, geçmişle hayli benzerlik barındırsa da yeni bir emek rejiminin ürünü olarak anlaşılmalıdır. Michael Burawoy'un emek rejimlerinin tarihsel gelişimini analiz etmek için kullandığı kavramsallaştırmasından göz önüne alındığında, taşeron çalışmanın hem despotik döneme, hem de hegemonik despotizm dönemine has unsurları barındıran, çelişkili bir bileşim olduğu açıkça görülecektir. Dolayısıyla, sistemin yıpratıcı etkilerinin giderilmesi, günümüze has, günümüz koşullarını gözeten yeni sosyal politika araçlarının yaratılmasıyla mümkündür.

\section{Kaynakça}

Andrade, R. D. C., 2002. Brazil: the economics of savage capitalism. Lua Nova: Revista de Cultura e Política, (57), 05-32.

Bell, D., 1974. Labor in the Post-Industrial Society. In: B. Silverman and M. Yanowitch, ed. The Worker in 'Post-Industrial' Capitalism: Liberal and Radical Responses. New York: Free Press, 91-95.

Berberoglu, B., 2002. Labor and Capital in the Age of Globalization. Maryland: Rowman \& Littlefield Publishers.

Bradley, H., Erickson, M., Stephenson, C. and Williams, S., 2002. Myths at Work. Cambridge: Polity Press.

Bratton, J., 1992. Japanization at Work: Managerial Studies for the 1990s. London: Macmillan Press.

Burawoy, M., 1985. The Politics of Production: Factory Regimes Under Capitalism and Socialism. London: Verso.

Doogan, K., 2001. Insecurity and long-term employment. Work, employment and society, $15(3), 419-441$. 


\section{(2017) Cilt 1(1)}

Ennals R., 1999. Policies for Occupational Health and Safety Management Systems and Workplace Change. In: Ennals R., ed. Work Life 2000 Yearbook 1 1999., London: Springer.

Enright, B., Pemberton, S., 2016. Strategies and tactics for local market making in the Temporary Staffing Industry. Geoforum 74, 9-18.

Ercan, F. ve Özar, Ş., 2000. Emek piyasası teorileri ve Türkiye'de emek piyasası çalışmalarına eleştirel bir bakış. Toplum ve Bilim, 86(2), 22-71.

Friedman, A., 1987. Specialist Labour in Japan: Computer Skilled Staff and the Subcontracting System. British Journal of International Relations, 25(3), 353-369.

Friedman, T., 2005. The World is Flat: A Brief History of the Twenty-first Century. New York: Farrar, Straus and Giroux.

Gorz, A., 2001. Yaşadı̆̆ımız Sefalet. Kurtuluş Çareleri (Çev. N. Tutal). İstanbul: Ayrıntı Yayınlar1.

Grint, K. and Woolgar, S., 1997. The Machine at Work. Cambridge: Polity.

Gutelius, B., 2015. Disarticulating distribution: Labor segmentation and subcontracting in global logistics. Geoforum, 60, 53-61.

Harvey, D., 1997. Postmodernliğin Durumu (Çev. S. Savran). İstanbul: Metis.

Harvey, D., 2010. Sermaye Muamması: Kapitalizmin Krizleri (Çev. S. Savran). İstanbul: Sel Yayınc1lik.

Harvey, D., 2012. Sermayenin Sınırları (Çev. U. Balaban). Ankara: Tan Kitabevi yayınları.

Hirschhorn, L., 1984. Beyond Mechanization: Work and Technology in a Postindustrial Age. Cambridge, Mass.: MIT Press. 


\section{(2017) Cilt 1(1)}

Holtgrewe U., Flecker J., Schönauer A. 2009. Flexibility and Restructuring of Value Chains: Findings from the WORKS Project. Paper presented to the Industry Studies Association, Chicago, 28-29 May,

https://www.researchgate.net/profile/Ursula_Holtgrewe/publication/228582935_Flexibility_a nd_restructuring_of_value_chains_findings_from_the_WORKS_project/links/54dc784f0cf2a 7769d963e7e.pdf

Husson, M. (2013). 10 Derste Kapitalizm (Çev. O. S. Binatl1). İstanbul: Habitus Kitap.

Kiely, R., 1998. Globalization, Post-Fordism and the Contemporary Context of Development. International Sociology, 13(1), 95-115.

Knights, D. and Murray, F. 1994. Managers Divided: Organizational Politics and Information Technology Management. London: Wiley.

La Botz, D., 2007. Latin America Leans Left: Labor and the Politics of Anti-Imperialism. New Labor Forum, 16(2), 60-70.

Marx, K., 2011. Kapital I (Çev. N. Satligan ve M. Selik). İstanbul: Yordam Kitap.

Mattelart, A., 2004. Bilgi Toplumunun Tarihi (Çev. H. Yücel). İstanbul: İletişim.

Okcan, N. ve Bakır, O., 2010. İşletmenin ve İşin Gereği Taşeronlaştırma: Taşeron Cumhuriyetine Doğru. Çalışma ve Toplum, 4, 55-74.

Piore, M. and Sabel, C. F., 1984. The Second Industrial Divide: Possibilities for Prosperity. New York: Basic Books.

Sennett, R., 2005. Otorite (Çev. K. Durand). İstanbul: Ayrıntı Yayınları.

Sennett, R., 2009. Yeni Kapitalizmin Kültürü (Çev. A. Onacak). İstanbul: Ayrıntı Yayınları.

Sennett, R., 2012. Beraber. (Çev. İlkay Özküralpli). İstanbul: Ayrıntı Yayınları. 


\section{(2017) Cilt 1(1)}

Thompson, P., 2003. Disconnected capitalism: or why employers can't keep their side of the bargain. Work, employment and society, 17(2), 359-378.

Taymaz, E., 1993. Kriz ve Teknoloji. Toplum ve Bilim 56, 5-41.

Tiyek, R., 2014. Devletin endüstri ilişkilerindeki rolü ve taşeron çalışma. Hak $\dot{I}_{s ̧}$ Uluslararası Emek ve Toplum Dergisi, 3 (7), 8-31.

Yücesan-Özdemir, G., 2010. Despotik emek rejimi olarak taşeron çalışma. Çalışma ve Toplum, 27(4), 35-50.

Zuboff, S., 1988. In the Age of Smart Machine: The Future of Work and Power. New York: Basic Books. 